\title{
ГРАМАТИКА
}

\section{СЕМАНТИЧНИЙ ПОТЕНЦІАЛ ЛОКАТИВНИХ ПРЕФІКСІВ}

У статті схарактеризовано сполучувальний ресурс, значеннєвий потенціал токативних префіксів. Вирізнено, зокрема, три семантичні групи просторових префіксів («місие діі», «напрям руху», «илях руху»), установлено семантичну структуру кожного конкретного репрезентанта иих груп, з'ясовано умови формування спектра диференційованих значень. Основну увагу приділено інтерпретуванню безпосередньої пребіксально-прийменникової корелячії, щзо є найважливішим маркером статичної, директивної (лативної, аблативної, лативно-аблативної) або транзитивної семантики. Проаналізовано також внутрішньосистемні зв'язки між пребіксами, передусім їхні синонімічні можливості.

Ключові слова: локативні префікси, статична, директивна, транзитивна семантика, прийменникові кореляти, префіксально-прийменникова кореляція, семантична диферениіація.

Stepanenko M. Semantic Potential of Locative Prefixes. The article analyses the semantic nature of locative prefixes in the Ukrainian language and reveals their role in the formation of the concrete differentiated meanings. Combinatory potential of the locative prefixes has been described. It has been proved that these prefixes regularly function as components of verbs denoting motion, in particular the directed motion, or a specific physical activity with a dynamic character, or an activity associated with motion. Semantic classification of the locative prefixes has been provided. This classification resembles the semasiological procedure of modelling the semantic structure of a particular word or several lexemes grouped together according to different semantic features and as such it includes several steps. First, the corpus of locative prefixes (о-/об-/обі-, в-/вві-/вi-/y-/yвi-, до-/ді-, за-, над-/наді-/надо-, під-/

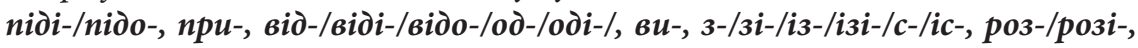
npo-, nepe-) is compiled. Then, three groups of the formants are discriminated: "place of action" [о-/об-, poz-/pozi-], "direction of motion" [в-/вві-/вi-/y-/yвi-, до-/di-, за-, над-/наді-/надо-, під-/nidi-/niдо-, при-, від-/віді-/відо-/од-/оді-/, ви-, з-/ 3i-/iz-/izi-/c-/ic-], and "route of the motion" [npo-, nepe-]. After that, the possible inner semantic relations in the groups are identified, in particular the directive prefixes are classified into lative [від-/вidi-/вido-/od-/odi-/, ви-, 3-/зi-/iz-/iзi-/c-/ic-], ablative [в-/вві-/ві-/y-/yві-, до-/ді-, за-, під-/nidi-/nido-, над-/наді-/надо-/, при-, роз-/poзi-, ви-, вid-/вidi-/вido-/od-/odi-]. The semantic potential of each of these 
morphemes is characterized, mono-, bi- and polysemantic formants are singled out. The main attention is devoted to the interpretation of the correlations between prefixes and prepositions, ascertainment of possible correlative types, explanation of the role of a prefix and its semantically correlative preposition in constructing specific differentiated meanings with the identification semes "place of action", "direction of motion: start or finish", and "route of motion". Besides, intersystemic relations between prefixes are traced with the emphasis on the synonymic potential of the prefixes.

Key words: locative prefixes, static, directive, transitive semantics, prepositional correlates, correlation of prefixes and prepositions, sematic differentiation.

\section{Вступ}

У мовознавстві утрадиційнився погляд про префікс як двобічну мовну одиницю. Однак, справедливо зауважує С. Соколова, «досі залишається дискусійними питання самостійності значення префікса, а отже, відповідно і правомірність дослідження семантичної структури префікса, введення його до системи семантичних відношень (полісемія, омонімія, синонімія), створення реєстрів префіксальних значень тощо» [Соколова, 2003: 11].

Метою пропонованої статті $€$ аналіз семантичного потенціалу просторових префіксів, з'ясування їхнього впливу на формування диференційованого типу локативності, установлення механізму корелювання з прийменниками як важливими маркерами локативності.

Порушена в науковій розвідці проблема знайшла своє неоднозначне розв'язання в багатьох лінгвістичних студіях. Ідеться передусім про праці І. Р. Вихованця, В. Г. Войцехівської, К. Г. Городенської, В. В. Ірещука, Т. А. Івасишиної, В. С. Ільїна, Є. А. Карпіловської, Н. Ф. Клименко, І. І. Ковалика, Л. М. Полюги, В. М. Русанівського, С. О. Соколової та ін.

\section{Методи й методики дослідження}

Специфіка досліджуваного об’єкта зумовила вибір адекватних методів дослідження. На основі описового методу узагальнено спостереження над фактичним матеріалом, здійснено аналіз семантичних типів префіксально-прийменникової кореляції; метод компонентного аналізу дав змогу виокремити лексико-семантичні групи дієслів, які сполучаються з локативними префіксами, з'ясувати роль префікса й семантично узгодженого з ним прийменника у формуванні локативно-статичних, локативно-директивних, локативно-транзитивних диференціальних значень. 


\section{Результати та дискусії}

Морфеми о-/об-/обі-, в-/вві-/вi-/y-/yвi-, до-/дi-, за-, над-/наді-/ надо-, nid-/niдi-/niдo-, nрu-, від-/вiдi-/вiдо-/од-/одi-/, ви-, 3-/зi-/iз-/iзi-/с-/ ic-, роз-/розі-, про-, пере-, які формують локативно-префіксальну парадигму, зазнають внутрішньої семантичної диференціації, в основі якої лежать різні критерії. Загалом же вона нагадує семасіологічну процедуру моделювання значеннєвої структури окремого слова або об'єднаних за різними семантичними ознаками лексичних одиниць.

Просторові префікси представлені такими основними семантичними різновидами: ті, які позначають місце дії, i ті, які вказують на напрям і шлях руху. Директивні префікси репрезентовані двома значеннєвими типами: «вихідний пункт руху (старт)» та «кінцевий пункт руху (фініш)». Внутрішня семантична диференціація префіксів - це поділ їх на рівні статичності, директивності або транзитивності на моно-, бі- й полісемантичні одиниці, вичленування в окремий тип морфем, які здатні реалізувати лативно-аблативні, лативно-транзитивні, аблативно-транзитивні відношення.

Склад префіксів із семантикою місця дії утворюють морфеми o-/ об-/обі- та роз-/розі-. За першою закріплене значення «поширення дії навколо просторового орієнтира», за другою - «охоплення дією з усіх боків просторового орієнтира». Кожен з аналізованих префіксів наділений своїми синтагматичними можливостями: o-/об-/обі- функціонує у складі дієслів руху та просторового переміщення (оббігти, облетіти, обвезти, обнести), роз-/розі-- у складі дієслів конкретної фізичної дії динамічного характеру (розікласти, розкидати, розбризкати, розіслати). Описуваним префіксам, як і будь-яким іншим, притаманний свій тип прийменникової кореляції: морфеми о-/ об-/обі-, роз-/розі- разом із дієсловами, з якими вони сполучаються, програмують прийменники, що вживаються з родовим відмінком й об’єднані інваріантною семантикою «з усіх боків»: навколо, довкола, кругом, навкруги, навкруг, довкіл, вколо, вкруг, круг, окіл, округ (розм.), округи (розм.), довкруги (розм.), довкруж (розм.), доокіл (розм.), напр.: Вихопивсь він [Яким] у бокові двері і обійшов кругом иеркви, гадаючи, щъо наздожене іï [Зосю] (І. Нечуй-Левицький); ...Василь по снігу i босоніж оббіг навколо Тернопільського ставу (Інтернет-ресурс); Того самого року, коли... космонавт Юрій Гагарін став першою людиною, щьо облетіла довкола Землі, американський астроном Френк Дрейк 
презентував свою жартівливу формулу, за якою можна вирахувати ймовірність першого контакту (Інтернет-ресурс); Сонце сховалося за мурами Ясс, коли козаки, добре повечерявщи, покотом розляглися навколо вогнищ, (Ю. Сорока); Установка інсталяції зайняла чотири дні: близвко 400 волонтерів розіклали навколо піраміди тисячі десятиметрових смужок із зображенням (Інтернет-ресурс); Та тумани хитаються, Понад селом згущаються, Розляглися по полях, Щоб затьмити людям илях (I. Франко).

Префікс роз-/розі- репрезентує також семантику «поширення дії в межах просторового орієнтира», коли входить до структури дієслів конкретної фізичної дії, що має динамічний характер, і корелює 3 прийменником ПО, який $є$ компонентом прийменниково-відмінкової форми ПО + Nloc, напр.: Воли їхні сиві розбрелися по зеленому довкіллю... (В. Триліс); Розсілись зорі по чудеснім, безконечнім, Блакитнім просторі... (С. Воробкевич).

Уже було зауважено, що для префіксів, які вказують на напрямок руху (в-/вві-/вi-/y-/yвi-, до-/дi-, за-, над-/надi-/надо-, під-/nidi-/ nido-, nрu-, від-/вidi-/вiдо-/od-/odi-/, ви-, з-/зi-/iз-/iзi-/c-/ic-), характерна зорієнтованість на реалізацію аблативних і лативних просторових відношень. Значення «старт» реалізують префікси від-/віді-/відо-/ од-/odi-, ви-, 3-/зi-/iз-/iзi-/c-/ic-. Моносемантичністю наділена морфема від-/віді-/відо-/од-/оді-. Вона актуалізує семантику «віддалення від об’єкта» в такому іiі конкретизованому вигляді, як «напрям руху від крайньої точки локативного орієнтира». Регулярними для цього просторового префікса $є$ функціонування у складі дієслів руху, динамічного переміщення, а також кореляція з однойменним прийменником, що побутує у структурі прийменниково-відмінкової форми ВІД/ ОД + Ngen, напр.: ...nостаті віддалялися від хати (Григорій Тютюнник); Від баштану віддаляється постать (М. Куліш); Ми... віддалилися від Черемошу (І. Муратов); Він відійшов від дверей (А. Дімаров); ... [австріяки] відтиснули руських від села (С. Пушик).

Префікс 3-/зi-/iz-/iзi-/c-/ic- здатний передавати кілька значень аблативності. Типовою для нього $є$ семантика «напрям руху з поверхні просторового орієнтира». Умови реалізації іiі - сполучення аналізованого префікса з дієсловами руху, просторового переміщення (збігти, звалитися, з'іхати, скочити, злізти, злетіти, зійти, сповзти, зіскочити, сплигнути, спуститися, стекти, зсипатися, скинути, 
звалити, звезти, звести, скотити, зсадити, зняти, стягти), кореляція з однойменним прийменником, що $є$ компонентом прийменниково-відмінкової форми 3-/3I-/I3 + Ngen, напр.: Сніг... зійшов з землі (М. Стельмах); Дівчата з горбів... не сходять (О. Олесь); Череда... скотилася з узгір’я (Б. Лепкий); Піт скапував з носа (В. Яворівський).

Префікс 3-/зi-/iз-/iзi-/c-/ic- експлікує також значення «напрям руху з простору вище від локативного орієнтира», коли сполучається з дієсловами руху і вступає в корелятивні зв'язки з прийменниками 3-НАД + Ngen, 3-ПОНАД + Ngen, напр.: Той порив... злетів 3-над небес (М. Драй-Хмара).

Найширший семантичний спектр має аблативний префікс ви-. Він бере активну участь у структуруванні значення «напрям руху 3 меж локативного орієнтира». Дієслова з досліджуваним префіксом об’єднуються типовим словотвірним значенням «рух або переміщення когось, чогось із середини назовні». Префікс ви-, слушно зауважує Т. П. Засухіна, «вносить просторову семантику в безпрефіксні дієслова руху і в ряд дієслів конкретної фізичної дії», причому «значення руху зсередини назовні є основним, вихідним» для нього (Засухина, 1991: 49). Тип безпосередньої префіксально-прийменникової кореляції з префіксом ви- утворює прийменник 3/3I/I3 як конституент прийменниково-відмінкової форми 3/3I/I3 + Ngen, напр.: Оксен вицшов з конюшні (Григорій Тютюнник); І вона... вибігла... з хоромини (В. Малик); Шиманський вийшов з кузні (В. Земляк);...з під'їзду вийшов Гонтар (Я. Баш). Рідше в корелятивні зв'язки вступають описуваний префікс і прийменник ВІД, що сполучається з генітивною словоформою, напр.: Що то за молодиия вийшла від нашої Марти? (Марко Вовчок); Він вийшов від корів (О. Маковей). Визначальною особливістю аналізованих синтаксичних конструкцій $є$ те, що в них припредикатну позицію разом із прийменником ВІД/ОД заповнюють іменники - назви істот, які репрезентують значення не реального, а метонімічного простору. Пор. подані вище приклади з такими їхніми трансформованими варіантами: Що то за молодиия вийшла з хати [двору...], де перебуває Марта; Він вийшов із сарая [корівника, загону, загороди], де перебувають корови.

За безпосередньою участю префікса ви- формуються такі значення, як «напрям руху з-за меж просторового орієнтира», «напрям руху з протилежного або зворотного боку вокативного орієнтира». 
Роль семантичного маркера в конструкціях із цими семантичними описами разом із префіксом виконує іменник у формі генітива, який сполучається з прийменниками-корелятами 3-3A/I3-3A + Ngen, 3-ПОЗА + Ngen, напр.: ...вибігли вони з-за ивинтаря (О. Кобилянська); Із-за лісу, з-за туману, місяиь випливає...(Т. Шевченко); Випливаєш з-за обрію ти (В. Симоненко); 3-поза морів висувається вечір (Б. Лепкий); Максим... вийшов з-поза стола (В. Стефаник).

Складником значеннєвого обсягу префікса ви- $€$ семантика «напрям руху з простору нижче від локативного орієнтира», якщо він сполучається з дієсловами руху, конкретної фізичної дії динамічного характеру й корелює з прийменниками 3-ПІД + Ngen, 3-ПОПІД + Ngen, напр.: Годований витяг з-під поли обріза (М. Куліш); ...із-під зруйнованих печищ вилізали... люди (О. Довженко); Вилинула 6 [я] 3-попід калини (Укр. нар. пісня); ... иуценятко висувалося 3-попід ї ліктів (М. Семенко).

До можливих компонентів системної багатозначності префікса вu-, який функціонує з дієсловами руху, переміщення, уналежнено такий, як «напрям руху з простору, оточеного локативними орієнтирами». Його реалізують у повному обсязі поряд із префіксом прийменники-кореляти 3-ПОМІЖ/3-ПОМЕЖИ + Ngen, 3-МЕЖИ/ 3-МІЖ + Ngen, 3-ПРОМІЖ/3-ПРОМЕЖИ + Ngen, призначення яких - указувати «на напрям руху з простору між окремими однорідними предметами» (Войцехівська, 1968: 62), напр.: Телебоніст вийшов 3-поміж дерев (О. Гончар); 3-поміж них [кіннотників] вискочив Якименко (Р. Купчинський); Та ось з-між двох... хмарок виглянуло... сонце (В. Бабляк); Вона... виступила 3-проміж... дерев (Ю. Смолич).

Префікс ви-, що регулярно сполучається з дієсловами руху та переміщення, семантично узгоджується 3 прийменниками 3-ПОЗАД + Ngen, 3-ПОЗАДУ + Ngen і конституює диференційоване значення «напрям руху із заднього боку локативного орієнтира», напр.: Хлопецьь вибіг з-позад хати (С. Воробкевич). Коли ж він перебуває у відношенні безпосередньої кореляції з прийменниками 3-СЕРЕД + Ngen, 3-ПОСЕРЕД + Ngen, то перебирає на себе роль одного з сутнісних носіїв семантики «напрям руху з умовного центру локативного орієнтира», напр.: Вийшов з-серед народу красень-молодик (Н. Забіла); ...висунувся 3-посеред товпи старий кремезний козак (А. Чайковський). 
Для префікса ви- можливим $\epsilon$ безпосередній корелятивний зв'язок із прийменниками ЗСЕРЕДИНИ / ІЗСЕРЕДИНИ + Ngen, отже, й участь у формуванні директивно-аблативної семантики «напрям руху зсередини локативного орієнтира», напр.: ...зсередини [залу]... вилазив котрийсь із слабогрудих (А. Головко); ... [він] висмикнув зсередини стогу жмут жита (Панас Мирний).

Значення «фініш» репрезентують префікси в-/ввi-/вi-/y-/yвi-, до-/ ді-, за-, під-/niдi-/niдо-, над-/наді-/надо-/, при-,роз-/розі-, ви-, від-/віді-/ відо-/од-/оді-. Для них, як і для репрезентантів аблативної семантики, типовою є сполучуваність із дієсловами руху, просторового переміщення, рідше - з вербативами конкретної фізичної дії, що має динамічний характер або асоціюється з рухом.

Однозначність властива префіксу до-. Він, корелюючи з прийменником ДО, що входить до прийменниково-відмінкової сполуки ДО + Ngen, реалізує семантику «напрям руху до просторового орієнтира без проникнення в нього», напр.: Хлопець дійшов до иеркви (В. Гжицький); Дійшли ми до Синопа (С. Тудор); ...вони дійшли до оселі Веремія (М. Стельмах). Для цього префікса характерні синонімічні зв'язки з префіксами під-/nidi-/niдо-, над-/наді-/надо-, напр.: ...він підповз до хати (М. Стельмах); Пара найкращих гнідих... підкотила до sанку (В. Малик); Степан надбіг до воза (А. Чайковський).

Моносемантичну структуру має префікс роз-/розі-. Значення «напрям руху з однієї точки в різні боки просторового орієнтира» реалізується тоді, коли він корелює з прийменниками НА + Nacc, B/У + Nacc, МІЖ / МЕЖИ + Nacc, ПОМІЖ / ПОМЕЖИ + Nacc, ПРОМІЖ / ПРОМЕЖИ + Nacc, напр.: Петро роззирався на різні боки (Ю. Мушкетик); Худоба розтеклась на різні боки (Панас Мирний); В різні боки розлетілись орлята (С. Васильченко); ...розбігаються дороги в усі кіниі свіmу (О. Довженко); ...вітер обтіпував з молодих топольок прижовкле листя і розкидав поміж могил (Григорій Тютюнник).

Префікс в-/вві-/вi-/y-/уві- конституює локативно-директивні значення «напрям руху в межі просторового орієнтира» $\mathrm{i}$ «напрям руху в простір, оточений локативними орієнтирами». Реалізуючи перший семантичний опис, він корелює з прийменниками ДО + Ngen, В/У + Nacc, НА + Nacc, ВСЕРЕДИНУ / УСЕРЕДИНУ + Ngen, ВГЛИБ (В ГЛИБ) / УГЛИБ (У ГЛИБ) + Ngen, напр.: До світлиці вбігла... невістка (Б. Лепкий); Студенти ввійшли до залу (О. Десняк); У місто 
греки в'їхали волами (Л. Костенко); ... [Христина] входила всередину вітряка (М. Стельмах); Вона зайшла на стадіон (В. Собко). Префікс в-/ввi-/вi-/y-/yвi- в цьому значенні перебуває в синонімічному зв'язку 3 префіксом за-, який також утворює тип безпосередньої кореляції 3 щойно проаналізованими прийменниками, напр.: До корівника займов Павло (П. Загребельний); Продан зайтов до... корчми (М. Павлик); Він зайшов у парк (Ю. Мушкетик); Уповноважений зайшов усередину приміщення (В. Стефак). Репрезентуючи друге значення, префікс в-/ввi-/вi-/y-/yвi- семантично узгоджується з прийменниками МІЖ /МЕЖИ + Ngen, ПОМІЖ / ПОМЕЖИ + Ngen, ПРОМІЖ / ПРОМЕЖИ + Ngen, напр.: Харитя увійшла межи жита (М. Коцюбинський); Між них [мальв] втиснеться вітер-збитошник (Б. Лепкий).

Полісемантичністю наділені лативні префікси за-, nid-/nidi-/nido-, ви-. Префікс за- експлікує, крім уже проаналізованої семантики «напрям руху в межі локативного орієнтира», значення «напрям руху за протилежний або зворотний бік просторового орієнтира», коли корелює з прийменниками $3 \mathrm{~A}+\mathrm{Nacc}$, ПОЗА + Nacc, напр.: Син забіг за оселю (О. Копиленко); ... [він] заховав люльку за ремінь (О. Кобилянська). Семантичне узгодження цього префікса 3 прийменником ПІД / ПІДІ / ПІДО + Nасс, ПОПІД / ПОПІДІ / ПОПІДО + Nасс стає умовою формування лативної семантики «напрям руху в простір нижче від локативного орієнтира», напр.: Заліз [кіт] з нею піठ припічок (В. Яворівський); Прибульиі заховалися попід столи (Г. Хоткевич). Префікс за- здатний репрезентувати й таке значення, як «напрям руху ззовні в межі простору, оточеного локативними орієнтирами». Він функціонує у складі дієслів фізичної дії динамічного характеру (застрелити, засунути, затиснути) і корелює з прийменниками МІЖ/МЕЖИ + Nacc, ПОМІЖ / ПОМЕЖИ + Nacc, ПРОМІЖ / ПРОМЕЖ + Nacc, що не втратили генетичного зв'язку з тим лексичним компонентом, від якого утворилися і стали «носієм функційної проміжковості» (Павлова, 1977: 146-147), напр.: Люди... забігали поміж городи (О. Гаврилюк), І... [він] свічку... застромив між пальиі (М. Коцюбинський); Е мене... затиснула поміж коліна шаровари (М. Коцюбинський).

Широкий семантичний діапазон має префікс nid-/nidi-/nido-. Про одне з його значень - «напрям руху до просторового орієнтира без проникнення в нього» - ішлося вище. Він може також сигналізувати 
про «напрям руху в простір вище відлокативного орієнтира». Цей тип аблативності реалізується тоді, коли префікс nid-/nidi-/niдо- корелює з прийменником НАД / НАДІ / НАДО + Nacc, ПОНАД / ПОНАДО + Nacс, ВИЩЕ + Ngen, ПОВЕРХ + Ngen, напр.: Піднісся він чолом над иарські піраміди (М. Зеров); Дишель... підносився вгору понад голову коней (К. Кобринська); ...[мислива рука] вище хмар піднесла нашу мову (В. Самійленко); Ми вище зір піднесем колоски (Д. Павличко). Семантичну структуру розглядуваної морфеми доповнює значення «напрям руху в передній бік локативного орієнтира». Його структурують поряд із дієслівним префіксом прийменники ПЕРЕД / ПЕРЕДІ / ПЕРЕДО + Nacc, ПОПЕРЕД + Nacc, наПр.: Перед sанок під’іхав віз (У. Самчук).

Неоднорідність щодо значення властива префіксу ви-. Один із його семантичних описів - указівка на «напрям руху за протилежний або зворотний бік локативного орієнтира». Вирізнене значення він реалізує разом із прийменниками $3 \mathrm{~A}+\mathrm{Nacc}$, ПОЗА + Nacc, утворюючи безпосередній тип префіксально-прийменникової кореляції, напр.: Син забіг за оселю (О. Копиленко); Богослов випровадив його аж за ворота (А. Свидницький); Сонечко спускалося за гору (Панас Мирний). Аналізований префікс репрезентує також семантику «напрям руху в умовну середину просторового орієнтира». Роль корелята виконують прийменники НАСЕРЕД + Ngen, ПОСЕРЕД + Ngen, напр.: Вона... насеред села вийде (Панас Мирний); Вони... викотили віз насеред двору (Григорій Тютюнник), ...nоети виходять посеред підвищення (В. Підмогильний). Семантичний спектр префікса ви- представляють і такі локативно-директивні значення, як «рух до локативного орієнтира, який рухається в протилежному напрямі» і «рух в напрямі перетину шляху переміщення локативного орієнтира». Перше 3 них реалізується за безпосередньою участю прийменників-корелятів НАЗУСТРІЧ, НАВСТРІЧ (розм.), НАВСТРІЧ ДО (розм.), НАСТРІЧУ (розм.), друге - прийменників-корелятів НАПЕРЕРІЗ, НАВПЕРЕЙМИ, напр.: Виходжу я назустріч вітру й сонцю (В. Яворівський); ... виходили... перекупки... навперейми селянам (Панас Мирний); Напереріз демонстрантам вискочила машина (Ю. Смолич).

Склад префіксів транзитивної семантики утворюють морфеми про- і пере-. За префіксом про- закріплені такі просторові значення: 1) «шлях руху через внутрішні межі локативного орієнтира»; 2) «шлях 
руху по поверхні, що являє собою якийсь простір»; 3) «шлях руху на незначній віддалі від локативного орієнтира», 4) «шлях руху в напрямі довжини локативного орієнтира»; 5) «шлях руху в напрямі ширини локативного орієнтира». Розряд дієслів, з якими сполучається аналізований формант, репрезентують лексеми на позначення самостійного або несамостійного руху чи переміщення (проїхати, пробігти, пронестися, прочмигнути, проскочити, провести, прокотити). Реалізуючи перше значення, префікс про- корелює з прийменниками ЧЕРЕЗ і КРІЗЬ, напр.: Пробігли втікачі через городи, соняшники, через леваду, гречку (О. Довженко); ...сторож прошкутильгав через коридор (Ю. Смолич); Вовк крізь шпарку пропхався до хліва (І. Франко); Вони пройшли крізв гори Карпати (У. Самчук). Експлікуючи друге значення, він семантично узгоджується з прийменником ПО, напр.: По підвісній рейці пролетіла вагонетка (С. Чорнобривець). Умовою для репрезентації третього значення є корелювання префікса про- з прийменником МИМО, ПОВЗ, ПОУЗ (діал.), ПОЗ (діал.), ПОПРОЗ (діал.), ПОПРИ (заст.), ПРОЗ (діал.), напр.: Дикі коні-тарпани... проскакували мимо Каховки (О. Гончар); Андрій пройшов мимо чения (О. Довженко); Повз Черниша пробіг Козаков (О. Гончар); ...nовз вікна пропливає... круп жеребия (Григорій Тютюнник); Ганка... проходила поуз нього (І. Франко). Четверте й п’яте значення актуалізуються тоді, коли описуваний префікс про- корелює з прийменниками ВЗДОВЖ / УЗДОВЖ, ВДОВЖ / УДОВЖ, ВПОДОВЖ / УПОДОВЖ, ВПРОДОВЖ / УПРОДОВЖ, ЗДОВЖ (розм.), ПОДОВШ (діал.), ПОЗДОВЖ (діал.), ПОВЗДОВЖ (діал.), ПОДОВЖ (діал.), ВПРОСТ / УПРОСТ (діал.) і ВПОПЕРЕК / УПОПЕРЕК, ПОПЕРЕК, напр.: А Умриборм провіз його уздовж вулиці (М. Стельмах); Він пройшов упоперек поля (І. Багряний).

Префікс пере- вирізняється моносемантичністю. Як і морфема про-, він реалізує семантику «шлях руху через внутрішні межі локативного орієнтира» й корелює з прийменниками ЧЕРЕЗ, КРІЗЬ та ПО, напр.: Переповзли ми через натовп (О. Десняк); Цезар уже перейшов через гори Альпійські (М. Зеров); Хлопець перейшов по сходах на другий бік вулииі (Ю. Смолич). Специфіка префікса пере- полягає в тому, що він синхронно може експлікувати або лативно-аблативні, або лативно-транзитивні, аблативно-транзитивні відношення. Найтиповішими його прийменниковими корелятами $€$ такі: -3 (ВIД) $<->$ 
В (ДО, НА) або ДО (В/У, НА) <-> ЧЕРЕЗ (КРІЗЬ, ПО), напр.: Сенцова перевезли з тюрми в лікарню на обстеження (Інтернет-ресурс); Влада Марокко перевезла сотні мігрантів з розташованих на півночі районів до південних регіонів крайни (Інтернет-ресурс); Іван з Оленою перейшли по вулиці Карла Людвіка аж до Коперника, звернули до «Повітової Січі» (Інтернет-ресурс); Вони перейчли через поле до огорожі (Інтернет-ресурс).

\section{Висновки}

Отже, префікси локативної орієнтації вирізняються семантичною поліфункційністю. Сполучаючись із неоднорідними стосовно значення дієсловами, іманентною характеристикою яких $є$ динаміка, і вимагаючи вживання відповідних семантично узгоджених з ними прийменників-корелятів, вони беруть участь у конституюванні того або того диференційованого локативного значення як органічного складника загальних планів змісту «місце дії», «напрям руху: старт або фініш», «шлях руху».

Перспективу дослідження вбачаємо в потребі вивчення взаємозв’язків префіксів іншої семантики з прийменниками в процесі змістового наповнення вислову.

\section{ЛІТЕРАТУРА}

1. Войцехівська В. Г. Прийменникове керування дієслів з префіксом ви-. Синтаксична будова украӥнської мови: (синтаксичні категорії і зв'язки). Київ: Наук. думка, 1968. С. 57-66. 2. Засухина Т. П. Пространственная семантика предлогов, приставок, падежей в современном русском языке: моногр. Уфа: Изд-во Башкирского унта, 1991. 79 с. 3. Павлова Р. Пространственные конструкции в древнерусском языке в сопоставлении с древнеболгарским языком: моногр. София: Изд-во Болг. АН, 1977. 239 с. 4. Соколова С. О. Префіксальний словотвір дієслів у сучасній українській мові: моногр. Київ: Наук. думка, 2003. 283 с.

\section{REFERENCES}

1. Voitsekhivska, V. H. (1968). Pryimennykove keruvannia diiesliv z prefiksom vy[Prepositional government of the verbs with the prefix вu-.]. Syntaksychna budova ukrainskoi movy: (syntaksychni katehorii i zviazky) - The syntactic structure of the Ukrainian language: (syntactic categories and relations), (pp. 57-66). Kyiv: Nauk. dumka [in Ukrainian]. 2. Zasuhina, T. P. (1991). Prostranstvennaya semantika predlogov, pristavok, padezhey v sovremennom russkom yazyike [Space semantics of prepositions, prefixes and cases in the Modern Russian language]. Ufa: Izd-vo Bashkirskogo un-ta [in Russian]. 3. Pavlova, R. (1977). Prostranstvennyie konstruktsii $v$ drevnerusskom yazyike $v$ sopostavlenii s drevnebolgarskim yazyikom : monografiya [Space constructions in the Old Russian language in comparison with 
the Old Bulgarian language: monograph]. Sofiya: Izd-vo Bolg. AN [in Russian]. 4. Sokolova, S. O. (2003). Prefiksalnyi slovotvir diiesliv u suchasnii ukrainskii movi : monohrafiia [Prefix derivation of verbs in the Modern Ukrainian language: monograph]. Kyiv: Nauk. dumka [in Ukrainian].

Степаненко Микола Іванович - доктор філологічних наук, професор, ректор Полтавського національного педагогічного університету імені В. Г. Короленка; вул. Остроградського, 2, Полтава, 36000, Україна.

E-mail: myk_ivan@ukr.net

http://orcid.org/0000-0002-6727-1265

Stepanenko Mykola - Doctor of Philology, Professor, Head of V. H. Korolenko Poltava National Pedagogical University; Ostrohradskoho Str. 2, Poltava, 36000, Ukraine.

Надійшла до редакції 30 жовтня 2019 року 